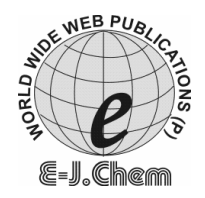

http://www.e-journals.net
ISSN: 0973-4945; CODEN ECJHAO

E-Journal of Chemistry

2009, 6(1), 89-92

\title{
Simple UV Spectrophotometric Determination of Rosuvastatin Calcium in Pure Form and in Pharmaceutical Formulations
}

\author{
ALKA GUPTA $^{* \#}$, P. MISHRA ${ }^{\S}$ and K. SHAH ${ }^{\S}$ \\ *Department of Pharmaceutical Sciences, \\ Dr. H.S. Gour Vishwavidyalaya, Sagar (M.P.), India. \\ ${ }^{\#}$ IPS College of Pharmacy, Gwalior (M.P.), India. \\ ${ }^{\S}$ GLA Institute of Pharmaceutical Research, Mathura-(U.P.), India. \\ alka0207@gmail.com
}

Received 19 May 2008; Accepted 10 July 2008

\begin{abstract}
A new, simple and sensitive spectrophotometric method in ultraviolet region has been developed for the determination of rosuvastatin calcium in bulk and in pharmaceutical formulations. Rosuvastatin exhibits absorption maxima at $244 \mathrm{~nm}$ with apparent molar absorptivity of $7.2345 \times 10^{4} \mathrm{~L} / \mathrm{mol} . \mathrm{cm}$ in methanol. Beer's law was found to be obeyed in the concentration range of $2-18 \mu \mathrm{g} / \mathrm{mL}$. The method is accurate, precise and economical. This method is extended to pharmaceutical preparations. In this method, there is no interference from any common pharmaceutical additives and diluents. Results of the analysis were validated statistically and by recovery studies.
\end{abstract}

Keywords: Spectrophotometric determination, Rosuvastatin calcium, Validated

\section{Introduction}

Rosuvastatin calcium (ROSU) is chemically bis [(E)-7 [4-(4-fluorophenyl)-6 isopropyl- 2[methyl (methyl-sulphonyl) amino] pyrimidin-5-yl] (3R, 5S) -3,5-dihydroxyhept-6-enoic acid] Calcium salt. It is a lipid-lowering drug $^{1-2}$. It inhibits the enzyme 3-hydroxy-3-methyl glutaryl coenzyme A (HMG-CoA) reductase, the rate limiting enzyme that converts HMGCoA to mevalonate a precursor of cholesterol and thereby checks the synthesis of cholesterol. It is used in the treatment of hyper-cholesterolemia and dyslipidemia ${ }^{3-4}$. A survey of literature ${ }^{5,6}$ showed few solid phase extraction using tandem MS, few LC-MS methods $^{7-9}$ and one HPTLC method ${ }^{10}$ for the estimation of ROSU in pharmaceutical preparations and in biological fluids. 
To the best of our knowledge, there is no report of UV-Visible spectrophotometric method for its estimation. Therefore, an attempt was made to develop a simple spectrophotometric method for the estimation of the present drug in formulations i.e. tablets.

\section{Experimental}

\section{Apparatus}

A GBC Cintra-10 double beam UV-Visible spectrophotometer (Australia) equipped with $10 \mathrm{~mm}$ matched quartz cells was used in the present investigation. A sartorius analytical balance was used.

\section{Chemicals and reagents}

Methanol (AR) (Qualigens) was used in the present study. Pure rosuvastatin obtained from $\mathrm{M} / \mathrm{s}$ Torrent Pharmaceuticals Ltd., Ahmedabad, was used as such without further purification.

\section{Recommended procedure and calibration curve}

ROSU (100 mg) was accurately weighed and dissolved in $100 \mathrm{~mL}$ methanol to form a stock solution $(1000 \mu \mathrm{g} / \mathrm{mL})$. The stock solution was further diluted suitably with methanol to get a working standard solution of concentration $100 \mu \mathrm{g} / \mathrm{mL}$. This working standard solution was suitably diluted to give a concentration of $14 \mu \mathrm{g} / \mathrm{mL}$ and this was then scanned in UV range. This showed an absorption maximum at $244 \mathrm{~nm}$ (Figure 1).Aliquots $(0.2,0.4 \ldots \ldots 1.8)$ $\mathrm{mL}$ of working standard solution corresponding to 2-18 $\mu \mathrm{g}$ were taken in a series of $10 \mathrm{~mL}$ volumetric flask and volume made up with methanol. The absorbance measurements of these solutions were carried out against methanol as blank at $244 \mathrm{~nm}$. A calibration curve of ROSU was plotted. The concentration of the unknown was read from the calibration graph or computed from the regression equation.

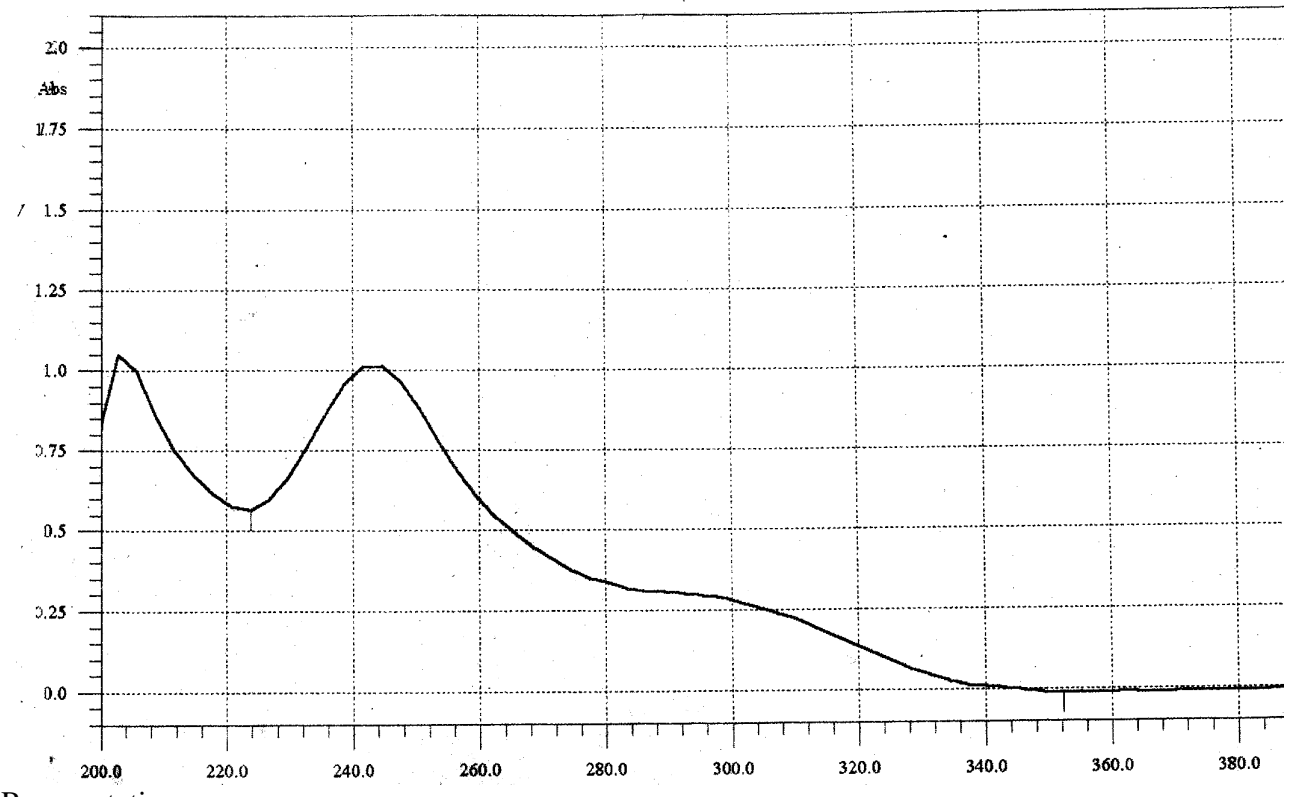

Rosuvastatin

Figure 1. Rosuvastatin scanned in UV range (in Methanol). 


\section{Procedure for tablets}

Two commercial formulation, fortius (M/s Nicholas Piramal) and rosuvas (M/s Ranbaxy Ltd.) were purchased from local market. The average weight of each tablet (before and after removing coating) was calculated by weighing 20 tablets. Ten tablets were powdered finely in a glass mortar. Powder equivalent to $50 \mathrm{mg}$ of rosuvastatin was successively extracted with methanol $(4 \times 20 \mathrm{~mL})$ and the extracts transferred quantitatively into $100 \mathrm{~mL}$ volumetric flask after filtering through Whatman No. 1 filter paper. The volume was then made up with methanol $(500 \mu \mathrm{g} / \mathrm{mL})$. Then this solution was further diluted with methanol to get working standard solution of $50 \mu \mathrm{g} / \mathrm{mL}$. Suitable volume of this solution was taken in $10 \mathrm{~mL}$ volumetric flask and volume was made up with methanol. Absorbances were read and concentrations of ROSU determined using the calibration curve. Calculations were then made with the dilution factor to find out the concentration of the drug in tablets. The experiments were repeated six times to check its reproducibility.

\section{Results and Discussion}

The proposed method for determination of ROSU showed molar absorptivity of $7.2345 \mathrm{x}$ $10^{4} \mathrm{~L} / \mathrm{mol} . \mathrm{cm}$. Linear regression of absorbance on concentration gave the equation $y=0.0726 x+0.001$ with a correlation coefficient (r) of 0.9978 (Table 1). Statistical analysis of commercial formulations has been shown in Table 2.

Table 1. Optical characteristics of ROSU.

\begin{tabular}{lc}
\hline Parameters & Values \\
\hline$\lambda_{\max }, \mathrm{nm}$ & 244 \\
Beer's Law Limit, $\mu \mathrm{g} / \mathrm{mL}$ & $2-18$ \\
Molar absorptivity, L/mol.cm & $7.2646 \times 10^{4}$ \\
Sandell's sensitivity & 0.0137 \\
$\left(\mu \mathrm{g} / \mathrm{cm}^{2} \times 0.001\right.$ absorbance unit) & \\
Regression equation & $\mathrm{y}=\mathrm{ax}+\mathrm{b}$ \\
Slope (a) & 0.0726 \\
Intercept (b) & 0.001 \\
Correlation coefficient $(\mathrm{r})$ & 0.9978 \\
\hline
\end{tabular}

Table 2. Statistical analysis of ROSU tablets.

\begin{tabular}{cccccc}
\hline $\begin{array}{c}\text { S.No } \\
.\end{array}$ & Brand & $\begin{array}{c}\text { Label claim } \\
\mathrm{mg} / \mathrm{tab}\end{array}$ & $\begin{array}{c}\text { Amount found } \\
\mathrm{mg} / \mathrm{tab}\end{array}$ & $\begin{array}{c}\text { \%Label } \\
\text { claim } \pm \mathrm{SD}^{*}\end{array}$ & SE* $^{*}$ \\
\hline 1. & $\begin{array}{c}\text { ROSUVAS } \\
(10 \mathrm{mg})\end{array}$ & 10 & 9.9904 & $9.99 \pm 0.0140$ & 0.0057 \\
2. & $\begin{array}{c}\text { FORTIUS } \\
(10 \mathrm{mg})\end{array}$ & 10 & 9.9892 & $9.98 \pm 0.0108$ & 0.0044 \\
\hline
\end{tabular}

*Average of six determinations

To evaluate the validity and reproducibility of the method, known amount of pure drug was added to the analyzed sample of tablet powder and the mixture was analyzed for the drug content using the proposed method. The percentage recovery was found to be within range (Table 3). Rosuvastatin exhibited maximum absorption at $244 \mathrm{~nm}$ and obeyed Beer's Law in the concentration range of $2-18 \mu \mathrm{g} / \mathrm{mL}$. The recovery experiments indicated the absence of interference from the commonly encountered pharmaceutical additives and excipients. 
Table 3. Recovery studies of ROSU tablets.

\begin{tabular}{ccccc}
\hline S.No. & Brand & Amount added, mg & Amount found, mg* & \%Recovery \pm S.D.* \\
\hline 1. & $\begin{array}{c}\text { ROSUVAS } \\
(10 \mathrm{mg})\end{array}$ & 10 & 59.9976 & $99.99 \pm 0.0766$ \\
2. & $\begin{array}{c}\text { FORTIUS } \\
(10 \mathrm{mg})\end{array}$ & 10 & 59.9563 & $99.92 \pm 0.0658$ \\
\hline
\end{tabular}

*Average of six determinations.

Thus it can be said that the proposed method is precise, accurate and economical which can be very well applied to the marketed samples.

\section{Acknowledgements}

The authors thank the Head of the Department for providing necessary facilities, and Torrent Pharmaceuticals Ltd., Ahmedabad, for providing the gift sample of rosuvastatin. The authors Alka Gupta and Kamal Shah thank the All India Council of Technical Education (AICTE), New Delhi for providing financial assistance.

\section{References}

1. Sweetman S C, Martindale The Complete Drug Reference, $34^{\text {th }}$ Ed., Royal Pharmaceutical Society of Great Britain, 2005, 996.

2. Lennernas H and Fager G, Clin Pharmacokinet., 1997, 32(5), 1234,

3. Osson A G, McTaggart F and Raza A, Cardiovasc Drug Rev., 2002, 20, 303.

4. McCormick A D, McKillop D, Butters C J, Miles G S, Baba T, Touchi A and Yamaguchi Y, J Clin Pharmacol., 2000, 40(9), 1055.

5. Hull C K, Penman A D, Smith C K and Martin P D, J Chromatogr B, 2002, 772, 219.

6. Hull C K, Martin P D, Warwick M. J and Thomas E, J Pharm Biomed Anal., 2004, 35, 609.

7. Singh S S, Sharma K, Patel H, Jain M, Shah H, Gupta S, Thakkar P, Patel N, Singh P and Lahray B B, J Braz Chem Soc., 2005, 16(5), 944.

8. Ravi K T, Raja R K, Ramesh M and Srinivas R, J Pharm Biomed Anal., 2005, 39, 661.

9. Kathaljne A, Oudhoff, Timothy S, Elizabeth T, Ian D and Wilson, J Chromatogr B., 2006, 832, 191.

10. Sane R T, Kamat S S, Menon S N, Inamdar S R and Mander R, J Planar Chromatography-Modern TLC, 2005, 18, 194. 


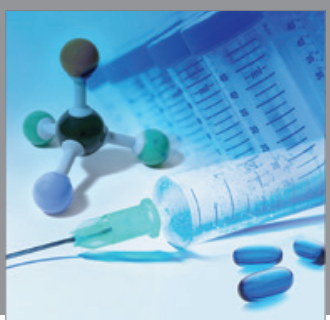

International Journal of

Medicinal Chemistry

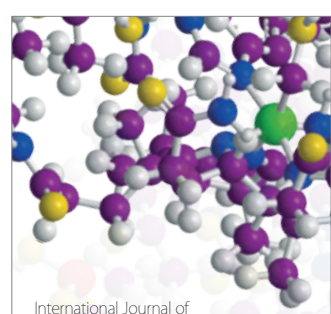

Carbohydrate Chemistry

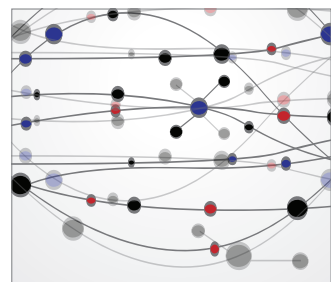

The Scientific World Journal
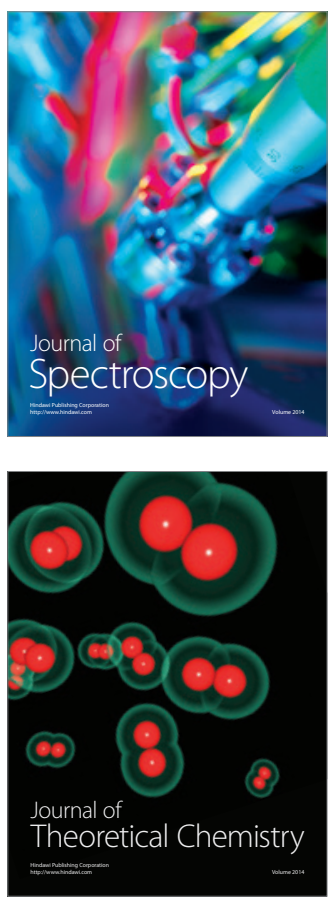
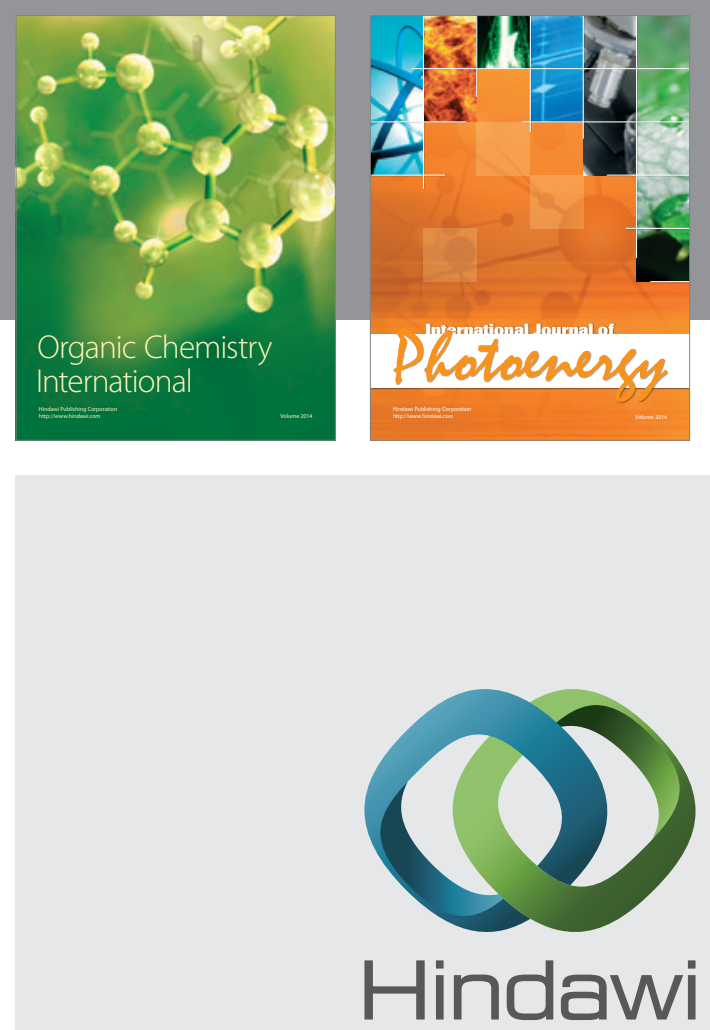

Submit your manuscripts at

http://www.hindawi.com
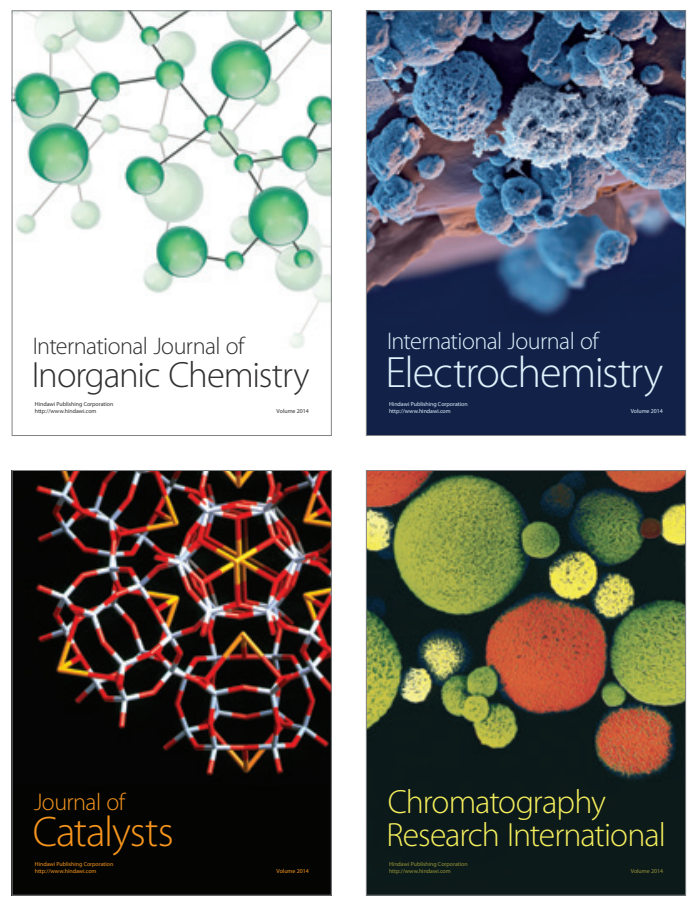
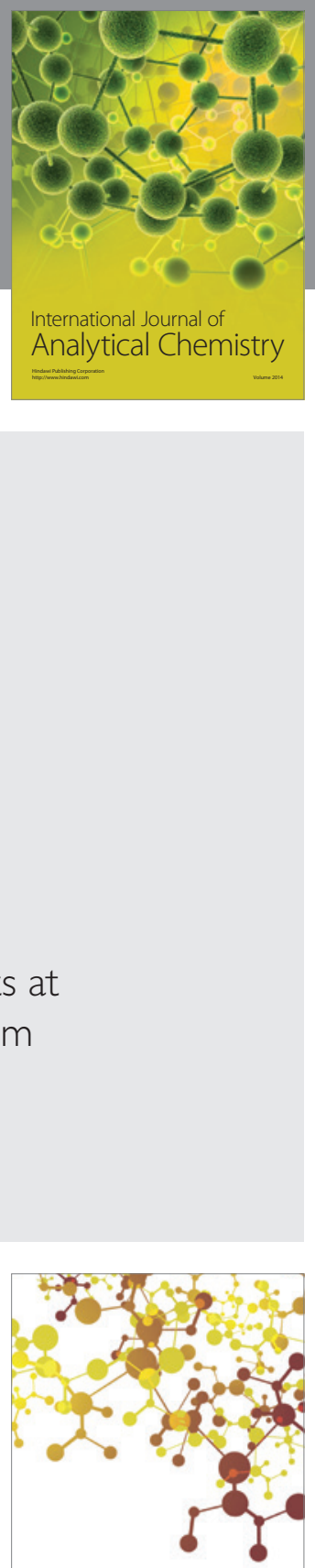

Journal of

Applied Chemistry
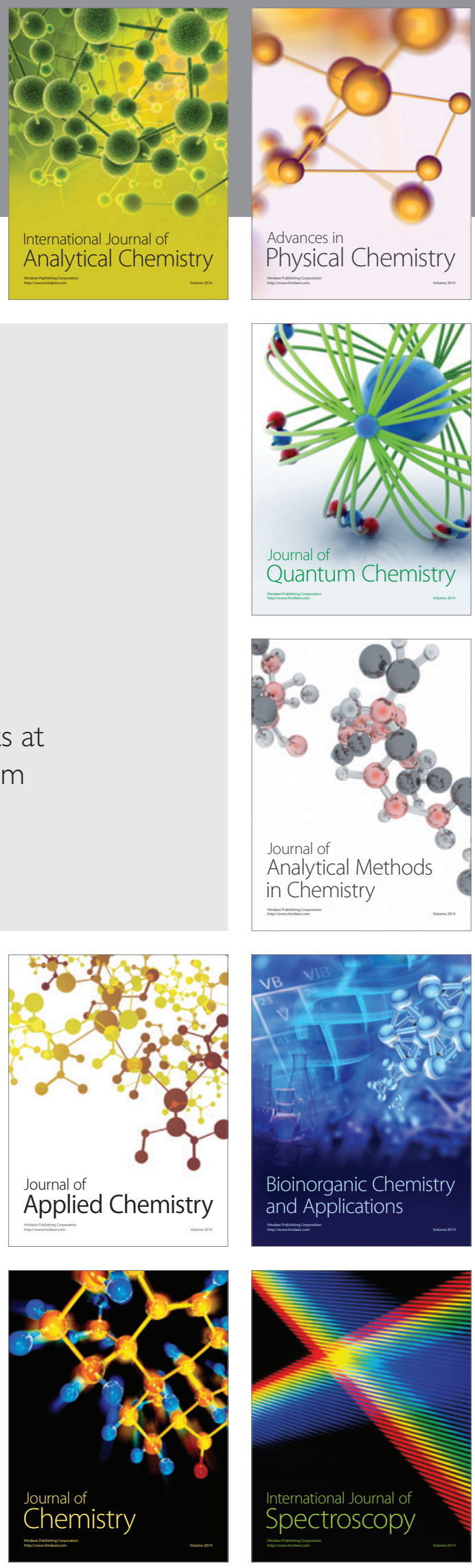